\title{
Investigating the Causes of Honeybee Colony Mobility in Central Rift Valley of Oromia, Ethiopia
}

\author{
Taye Beyene* Mekonen Woldatsadik \\ Oromia Agricultural Research Institute, Adami Tulu Agricultural Research Center, Zeway, Ethiopia
}

\begin{abstract}
The study was conducted in three selected districts of central rift valley of Oromia, Ethiopia with the objective to assess and prioritize the reasons of honeybee colony mobility. For this study, six peasant associations (PAs) were selected using purposive sampling techniques. From each PA, 20 beekeepers (a total of 120) were randomly selected and interviewed using pre-tested, structured questionnaires. The collected data were analyzed using Statistical Package for Social Sciences (SPSS) version 20.0 software and descriptive statistics. Results of the study showed that the mean age of the respondents was 46.54 years, indicating an active and productive age. The beekeepers had an average experience of 5.76 years where male respondents $(89.2 \%)$ take the largest share to be engaged in beekeeping activities. Ranking revealed that pests, predators and Diseases (17.6\%), shortage of bee forage (15.8\%), unwise application of agrochemicals $(15 \%)$, honeybee colony absconding and migration $(10 \%)$, shortage of bee colony (9.4\%), high cost of honeybee equipments and accessories $(8.1 \%)$, recurrent drought and deforestation (6.8\%), shortage of water $(4.6 \%)$, lack of knowledge $(3.6 \%)$, poor extension services $(2.7 \%)$, poor hive management $(2.7 \%)$, inadequate of business support services $(2.1 \%)$ and bee poisoning from plants $(1.5 \%)$ the main constraints of beekeeping in the study area in their order of importance. The main causes of colony absconds and migration in the study area were pests and predators $(21 \%)$, shortage of bee forage and water (20.6\%), incessant disturbance or poor hive management (18.3\%), unwise application of agrochemicals (13.9\%), unfavorable weather condition (8.1\%), in appropriate of honey harvesting techniques (3.97\%) and unknown reasons $(2.2 \%)$. The main month in which colony absconding occurs is from December to February. Beekeepers in the study area prevent the incidence of swarming by using large volume of hive (33\%), suppering of hive (26\%), removal of queen cells (19.7\%), killing new emerged queen (11.7\%) and swarming return back to the colony $(10 \%)$. The study demonstrated that honey productions in the study area are hampered by several constraints and challenges. Therefore, large scale and comprehensive research on constraints and honeybee diseases are highly recommended to take in preventing colony mobility as identified in this study.
\end{abstract}

Keywords: Absconding, constraints, honeybee, colony mobility, pests, swarming

DOI: $10.7176 / \mathrm{FSQM} / 108-01$

Publication date:May $31^{\text {st }} 2021$

\section{Introduction}

Beekeeping is an important venture used for strengthening the livelihood of rural community. It generates a variety of production and respective assets (Qaiser et al., 2013). Besides this the role played by honeybee in food security by increasing the productivity of crop through intensifying pollination is the already established fact. Beekeeping is exceptionally sustainable as the activity has no impact on the environment and rather it stabilizes fragile area and help in reclaiming degraded lands increase biodiversity (Adgaba et al., 2014).

Ethiopia is the home of diverse fauna due to its varied ecological and climatic conditions (Adgaba, 2007). The ideal climatic conditions and diversity of floral resources allow the country to sustain around 10 million honeybee colonies, of which 7 million are kept in local beehives by farmers and the remaining exist in the forests as wild colonies. This makes the country to have the highest bee density in Africa (Ayalew, 2001; Nuru, 2002). Ethiopia, having the highest number of bee colonies Ethiopia has the potential to produce 500,000 tons of honey and 50,000 tons of beeswax per annum but currently production is limited to 53,675 tons per annum (CSA, 2012a). This shows that the country is producing around $10 \%$ of its potential (CSA 2012a). Despite the long tradition of beekeeping in Ethiopia, having the highest bee density and being the leading honey producer as well as one of the largest beeswax exporting countries in Africa, the share of the sub-sector in the GDP has never been commensurate with the huge numbers of honeybee colonies and the country's potentiality for beekeeping. Productivity has always been low, leading to low utilization of hive products domestically and relatively low export earnings. Consequently, the beekeepers in the central rift valley of Oromia particular and the country in general are not benefiting from the sub sector (Nuru, 2002; Beyene and David, 2007).

Ethiopia has immense natural resources for beekeeping activity. However, like any other livestock sector, this sub sector has been seriously devastated by complicated constraints. The prevailing production constraints in the beekeeping sub sector of the country would vary depending on the agro ecology of the areas where the activities is carried out (Edessa, 2002). One of the prominent factors for this low honey production and productivity is the unpleasant behaviors of bees (aggressiveness, swarming tendency and absconding behaviors).

Investigation indicated that the number of the honeybee colonies in the country has been declining (CSA. 
1995) and consequently the honey and beeswax production as well as export earnings fell down (Gezahegne, 2001b). In Ethiopia, the population of domestic colonies has decline from 5.15 million in 2009 (CAS, 2009) to 4.99 million in 2011 (CAS, 2012). As a result, it is becoming more difficult to obtain adequate swarms to start bee farms and expand the existing apiary (Nuru and Dereje, 1999). According to Tessega (2009) report, beekeeper looses on average 2.60 colonies per household and 582.84 birr losses from 2.6 colonies per year per due to colony absconding in Bure district of Amhara region. Gidey et al, (2012) also reported that, colony absconding resulted in a total of 429 traditional and 297 modern beehives were without honeybee colonies representing an annual maximum loss of about US\$28,875 and 54,831, respectively in Asgede Tsimbla district, Northern Ethiopia. Colony absconding has great contribution for the decline in the population of honeybee colonies (Yigzaw et al., 2010). Depending on these realities, there is no research information regarding to the main reasons of honeybee colony mobility in the study central rift valley of Ethiopia. Therefore, the study was initiated to assess and prioritize the main reasons of honeybee colony mobility in the study area.

\section{Materials and methods \\ Description of the study area}

The study was conducted in three districts (Adami Tulu, Arsi Negele and Kofale) of Oromia Regional State. The districts were selected based on their potential for beekeeping; representing three agro-ecologies (low altitude, mid altitude lands and high altitude areas). Kofale district is located in West Arsi Zone of the Oromia Regional State about $305 \mathrm{~km}$ from Addis Ababa towards Southern direction. The area has an altitude and longitude of 70 00 ” N $38045 \mathrm{E} / 7 \mathrm{~N} 38.750 \mathrm{E}$. The annual average rainfall of area is about $1232 \mathrm{ml}$ with a mean monthly rainfall of $102.6 \mathrm{ml}$. The mean monthly minimum and maximum temperatures are about $5.40 \mathrm{C}$ and $19.80 \mathrm{C}$, respectively (OFEDO, 2009). Arsi Negele district is also located in west Arsi zone, Oromia Regional State about $225 \mathrm{~km}$ south of the capital, Addis Ababa. Geographically, it is situated in the Ethiopian central rift valley system of $7^{0} 09^{\prime}-7^{0} 41^{\prime} \mathrm{N}$ and $38^{0} 25^{\prime}-38^{0} 54^{\prime} \mathrm{E}$. The annual temperature varies from $10-25^{\circ} \mathrm{C}$ with annual rainfall between $500-1000 \mathrm{~mm}$. The altitude ranges from 1500-3000 m above sea level. Adami Tulu Jido Kombolcha district is located in Oromia region, East Shoa Zone about $167 \mathrm{~km}$ south of Addis Ababa, the capital city of Ethiopia. The district is geographically located at latitude of 70 50' North and longitude of 380 42'Eas. The district is located between $38^{\circ} 20^{\prime}$ and $38.5^{\circ} 5^{\prime} \mathrm{E}$ and $7^{\circ} 35^{\prime}$ and $8^{\circ} 05^{\prime} \mathrm{N}$. It lies at altitudinal range from 1500 to $2000 \mathrm{~m}$ above sea level.

\section{Sampling method and sample size determination}

Prior to the actual survey, information was gathered from secondary data and informal survey from key informants. Based on the information obtained from secondary data and informal survey, a structured questionnaire was developed. For this study, multi-stage sampling procedures were employed. In the first stage, three districts were selected purposively considering different agro-ecology, vegetation potential, honeybee colonies potential and accessibility to the road. In the second stage, 120 beekeepers were selected from identified from honey producer farmers using systematic random sampling technique taking into account probability proportional to size of beekeepers in each of six selected rural kebeles. Due to heterogeneity of the population beekeepers the sample size was determined according to Thrusfield (2005) with 95\% confidence interval and 5\% absolute precision.

$\mathrm{N}=\frac{1.96^{2} \mathrm{Pexp}(1-\mathrm{Pexp})}{\mathrm{d}^{2}}$

Where,

$\mathrm{N}=$ required sample size

Pex $=$ expected prevalence $=50 \%$

$\mathrm{d}^{2}=$ desired absolute precision $=5 \%$

\section{Methods of Data collection}

The research mainly focused on both primary and secondary data related to colony mobility were collected to achieve the objectives of this study.

\section{Formal survey}

Primary data were collected using quantitative approach by means of household survey using a set of pre-tested questionnaires. The qualitative method of data collection was also employed. The questionnaire was designed to capture information such as: household demographics including sex, marital status and age of the respondent, types and sources of hive used the swarming and absconding incidences, colony inspection and constraints of beekeeping. Secondary data was collected from district's livestock resource and fisher office, Regional Bureau, NGOs and other published and unpublished materials. Primary data were collected using semi-structured questionnaire, informal discussion with groups and key informants. Pre-test and recognizance survey were also 
conducted to see effectiveness of the questionnaire for the study and then the interviewed was conducted with the selected respondents to generate the relevant data by using structured questionnaire survey and check lists.

\section{Field observation}

Field observation was made on beekeeping and management practices, beehive types, honeybee pests and predators were observed to strengthen the information obtained.

\section{Key informant interview}

Key informant interview have been made with all study district beekeeping experts, development agents (DAs) of the study districts, some individual beekeeper farmers. The qualitative information collected in interview is used to supplement and crosscheck the data obtained through the household survey.

\section{Focus group discussions}

In addition to survey questionnaire, focus group discussion was employed to increase the consistency of data collected by other methods. The participants were selected purposefully from smallholder beekeepers, experts of livestock, PA leaders, DAs and bee technicians who are believed to be knowledgeable about beekeeping in order to extract the intended empirical data from the discussions.

\section{Data management and statistical analysis}

The collected data were coded, managed and analyzed using Statistical Package for Social Sciences (SPSS) version 20. Descriptive statistics such as mean, standard deviation, frequency and percentage were used to analyze the data.

\section{Results and Discussions}

\section{Demographic and Socio-Economic Characteristics of the respondents}

This section provides the profile of the sample respondents with regard to their age, sex, education level, family size, and beekeeping experience.

Out of the total sampled households in the study area, $89.2 \%$ were male-headed and the rest $10.8 \%$ were female headed households. The survey result indicates that beekeeping activity in the study area is dominated by male. This very limited number of female participation agrees with Adebabay (2008). The traditional hives are hanging on big tree branches in which some of the trees are as long as 40 meters and above. Female cannot climb up such big trees and hence discouraged to engage in the activity. Thus beekeeping is traditionally male dominated in the study area. Educational level of the farming households may have significant importance in identifying and determining the type of development and extension service approaches. Regarding the level of education, 35 percent of those interviewed beekeepers did not receive any formal or informal education. The rest were at different stages of literacy ranging from reading and writing skills to completion of college diploma and above (Table 1). Regarding the marital status, most of the household heads surveyed (95\%) were married with only 2.5 percent divorced (Table 1). The result of the majority being married indicated that apiculture business was dominated by responsible and matured people who could take decisions jointly with their spouses on their beekeeping business. This finding agrees with reports of Haftu and Gezu, (2014). Table 1: Sex, Educational and marital status of beekeepers $(\mathrm{N}=120)$

\begin{tabular}{|c|c|c|c|}
\hline Variables & Category & Frequency & $\%$ \\
\hline \multirow[t]{2}{*}{ Sex of respondents } & Male & 107 & 89.2 \\
\hline & Female & 13 & 10.8 \\
\hline \multirow[t]{6}{*}{ Educational level } & Illiterate & 42 & 35 \\
\hline & Can read \& write & 24 & 20 \\
\hline & Grade1-4 & 20 & 16.7 \\
\hline & Grade $5-8$ & 18 & 15 \\
\hline & Grade 9-12 & 12 & 10 \\
\hline & Diploma \& above & 4 & 3.3 \\
\hline \multirow[t]{3}{*}{ Marital status } & Single & 2 & 1.7 \\
\hline & Married & 114 & 95 \\
\hline & Divorced & 3 & 25 \\
\hline
\end{tabular}

The mean age of the beekeepers in the study area was 46.54 years (Table 2). This survey result showed that people in the most productive age are actively engaged in beekeeping activities with an average experience of 5.76 years (table 2). This survey result showed that people in the most productive age are actively engaged in beekeeping activities. Peoples in the aforementioned age do have the skill \& strength to climbing big trees and 
uplift the hive to hang on branches of big trees. Similarly, a study conducted in Tigray region by Tezera (2013) noted that the age group between 15 and 60 years are considered economically active age group and majority of households in younger age were more likely be energetic in beekeeping activities. Regarding experience sampled household practicing beekeeping on average about 5.77 with maximum 40 years. The level of beekeepers' experience was taken to be the number of years that an individual was continuously engaged in beekeeping. This is what one would expect in a situation where people are actively engaged starting from an early age in helping older beekeepers to undertake basic tasks. Family size serves as a form of family labor and compliments the effort of the household heads on the farm (Martey et al., 2013). The average family size of the sample farmers during the survey period was 6.24 persons, with maximum and minimum family size of 1 and 12 persons, respectively (Table 2). Family size serves as a form of family labor and compliments the effort of the household heads on the farm (Martey et al., 2013). The respondents having higher number of family size created an opportunity of beekeeping and crop production at household level that was in agreement with the results of Seyoum et al. (2018), Jinanus and Tamiru (2016) and Workneh (2007). The mean land holding per beekeeper household was estimated to be 1.58 ha. Generally, the average land holding in the study area showed insignificant difference but is slightly higher than the national average household land holding of 1.0-1.5 ha (ASE AIFSP, 2002).

Table 2: Socio-economic indicators of the sample respondents $(n=120)$ in the study area

\begin{tabular}{llllll}
\hline Socio-economic indicators & $\mathrm{N}$ & Minimum & Maximum & Mean & SD \\
\hline Age of house hold (year) & 120 & 22.00 & 72 & 46.54 & 1.87 \\
Beekeeping experience (year) & 120 & 1.00 & 40 & 5.76 & 1.96 \\
Family size (\#) & 120 & 1.00 & 12 & 6.24 & 2.42 \\
Land holding (hectare) & 120 & 0.25 & 10 & 1.58 & 2.00 \\
\hline
\end{tabular}

$\mathrm{N}=$ number of respondents, $\mathrm{SD}=$ standard deviation

\section{Type of beehive used in the study area}

Based on their level of technological advancement, there are three types of beehives used for honey production in the study area. These are traditional, intermediate and movable frame beehives. Of the total sample households, $(52 \%)$ household heads owned traditional hive followed by transitional hive (12.5\%), both traditional and transitional hives (11.7\%), all the three types of hives $(9.2 \%)$, movable frame hive $(8 \%)$, transitional and movable frame hives (6.6\%) respectively (Table 3). In the study area the activity is predominated by traditional practices since the majority of the respondents hardily understand new technologies. This finding is definitely different from national beehive usage status i.e. $95 \%$ of the beekeepers are traditional beehive owners but the rest are modern and transitional beehives owners (CSA, 2013). The current study was in agreement with Beyene and David (2007) who reported traditional, intermediate and modern beehives are used for honey production in Ethiopia. Traditional hive in most cases can be constructed by beekeepers from locally available materials. According to the survey results beekeepers preferred traditional hive for its convenience to construct, quantity of wax produced, cost effectiveness, less dependency on external inputs and used as bait swarming. However, beekeepers agreed on that traditional beehive are not productive, easily liable to pests and characterized by their low quality bee product harvest. According to sample respondents, top bar hive is preferred for its better quality of honey and requirement of little knowledge and accessories. On the other hand, moveable frame hive is preferred for its better quantity and premium quality of honey and suitable for harvesting. However, it is costly, requires skill and accessories

Table 3: Owned different beehive types by the respondents in the study area

\begin{tabular}{lll}
\hline Types of hive owned & Frequency & $\%$ \\
\hline Traditional beehive only & 62 & 52 \\
Transitional beehive only & 15 & 12.5 \\
Traditional and transitional & 14 & 11.7 \\
All the three types of hives & 11 & 9.2 \\
Frame beehive only & 10 & 8 \\
Transitional and movable frame hives & 8 & 6.6 \\
\hline
\end{tabular}

Honey yield from different types of beehive

As shown below in (Table 4), the average honey yield obtained from traditional, transitional and frame per hive per year were $5.7 \mathrm{~kg}, 12.2 \mathrm{~kg}$ and $18.7 \mathrm{~kg}$ in the study area, respectively. This survey result was agree with the national average of $5 \mathrm{~kg}$ (Gezahegn, 2001 and EARO, 2000) $12-15 \mathrm{~kg}$ and 15-20kg (MOA, 2003) for traditional, intermediate and movable frame hives, respectively. 
Table 4: Average of honey yields from different hive types in the study area

\begin{tabular}{|c|c|c|c|}
\hline \multirow[t]{3}{*}{ Districts } & \multicolumn{3}{|c|}{ Honey yield $(\mathrm{kg}) /$ hive /year } \\
\hline & Traditional hive & Transitional hive & Frame hive \\
\hline & Mean \pm SE & Mean \pm SE & Mean \pm SE \\
\hline Adami Tulu & $4.2 \pm 0.37$ & $9.46 \pm 0.12$ & $16.2 \pm 1.53$ \\
\hline Arsi Negele & $5.7 \pm 1.70$ & $12.7 \pm 1.25$ & $18.4 \pm 0.12$ \\
\hline Kofale & $7.3 \pm 0.57$ & $14.5 \pm 0.65$ & $21.5 \pm 0.14$ \\
\hline Overall mean & $5.7 \pm 0.76$ & $12.2 \pm 1.3$ & $18.7 \pm 1.08$ \\
\hline P-value & $\mathrm{P}>0.05$ & $\mathrm{P}<0.05$ & $\mathrm{P}<0.05$ \\
\hline
\end{tabular}

\section{Honey production trends in the study area}

The majority of the respondents $(88.6 \%)$ observed decreasing trends honey production due to shortage of bee forages, colony absconding, decreasing in the number of bee colonies, drought, pesticides and herbicide application, lack of water, lack of improved bee hives and poor management and in order of importance. This result agrees with the results of Tessega (2009) who stated that honeybee products production in Bure district was in a decreasing trend due to shortage of bee forages, drought, pesticides and herbicides application, lack of water and poor management.

Table 5: Trend in honey production from traditional, transitional and frame hives during 2014-2018 in the study area

\begin{tabular}{llll}
\hline Year & Traditional hive & Transitional hive & Framed hive \\
& Honey production in $(\mathrm{kg})$ & Honey production in $(\mathrm{kg})$ & Honey production in $(\mathrm{kg})$ \\
\hline 2014 & 2181 & 279 & 202 \\
2015 & 1464 & 184 & 162 \\
2016 & 1553 & 122 & 220 \\
2017 & 1337 & 103 & 161 \\
2018 & 1274 & 72 & 128 \\
\hline
\end{tabular}

Source: Survey result, 2018

\section{Sources and placement of honeybee in the study area}

Sample beekeepers were interviewed to describe their sources of foundation colony, $(76 \%)$ of the respondents declared that they have got their establishing colonies by catching swarms (hanging bait hives on the apex of trees) followed by gift from parents and catching swarms $(7.3 \%)$, through inheritance $(6.9 \%)$, gift from parents $(3.73 \%)$, purchased $(3.3 \%)$, given by government and NGOs $(2.7 \%)$ (Table 6$)$. The study results agree with (Gebretsadik and Negash, 2016; Kinati et al., 2012) who reported that catching swarm was the dominant source of honeybee colonies in the different parts of Ethiopia. Conversely, a study conducted by Guesh (2015); in selected Zones of Tigray Region, which reported that about $34.9 \%$ of the respondents declared that got their establishing colonies by purchasing from the market places and beekeepers. The study result also revealed that most of the respondents kept their honeybee colonies in the backyard of the house $(49.83 \%)$, under the roof of the house $(27 \%)$, hanged on the trees near home stead $(14.7 \%)$, hanged in the forest away from home stead $(4.7 \%)$ and kept in the areas of enclosure (3.73\%). This finding is agrees with the research finding of Seyoum et al. (2018); Kalayu, et al (2017), who reported that most beekeepers placed their honeybee colonies at backyard in different parts of Ethiopia.

Table 6: Means of colony getting and placement of honeybee colony in the study area

\begin{tabular}{|c|c|c|c|c|c|}
\hline Sources of colony & $\begin{array}{l}\text { Adami } \\
(\mathrm{N}=40 \%)\end{array}$ & Tulu & $\begin{array}{l}\text { Arsi Negele } \\
(\mathrm{N}=40 \%)\end{array}$ & $\begin{array}{l}\text { Kofale } \\
(\mathrm{N}=40 \%)\end{array}$ & $\begin{array}{l}\text { Total } \\
(\mathrm{N}=120 \%)\end{array}$ \\
\hline Catching swarms & 79.1 & & 76.6 & 72.4 & 76 \\
\hline Gift from parents and catching swarms & 7.4 & & 4.3 & 10.2 & 7.3 \\
\hline Inheritance & 5.5 & & 10 & 5.2 & 6.9 \\
\hline Gift from parents & 2.7 & & 5 & 3.5 & 3.73 \\
\hline Purchased & 3.2 & & 1.6 & 5.1 & 3.3 \\
\hline Given by government and NGOs & 2 & & 2.5 & 3.6 & 2.7 \\
\hline \multicolumn{6}{|l|}{ Placement of honeybee colonies } \\
\hline In the backyard & 57.5 & & 49.8 & 42.2 & 49.83 \\
\hline Under the roof of the house & 26 & & 24.2 & 31 & 27 \\
\hline Hanging on the trees near home stead & 10 & & 18.6 & 15.4 & 14.7 \\
\hline Hanging in forest away from home stead & 2.5 & & 5.1 & 6.4 & 4.7 \\
\hline In areas of enclosure & 4 & & 2.2 & 5 & 3.73 \\
\hline
\end{tabular}




\section{Honeybee colony inspection}

Sample respondents were interviewed to describe the frequency of inspecting their apiary and honeybee colonies. Majority (38\%) of the respondents replied that they inspect their honeybee colonies externally if necessary followed by at every month (23\%), every week (18\%), every fifteen day $(17 \%)$ and every day $(4 \%)$ respectively (Table 7). Moreover, majority $(56 \%)$ of the respondent replied that they inspect their honeybee colonies internally if necessary followed by at every month $(22 \%)$, every week $(14 \%)$ and every fifteen day $(8 \%)$ respectively. The study in line with the finding of Getachew (2018); Haftu and Gezu (2014); regarding to internal inspection of their bee colonies, large number of respondent beekeepers $(79.3 \%)$ of them reported as they inspected not at all except honey harvesting. Correspondingly, Gebretsadik et al. (2016) reported that beekeepers do not inspect hive internally unless to check either the hive was filled with honey or not. Internal hive inspection by opening the hive is not a common practice in the central rift valley of Ethiopia due to the difficult of the traditional hives for internal inspection since fixed combs attached to the body of traditional beehive unless to check either the hive was filled with honey or not.

Table 7: External and internal hive inspection frequency by sample respondents

\begin{tabular}{lllll}
\hline Inspection frequency & Internal & & External & $\%$ \\
& Frequency & $\%$ & Frequency & 4 \\
Every day & - & - & 5 & 18 \\
Every week & 17 & 14 & 22 & 17 \\
Every fifteen day & 10 & 8 & 20 & 23 \\
Every month & 26 & 22 & 28 & 38 \\
If necessary & 67 & 56 & 46 & \\
\hline
\end{tabular}

\section{Occurrence of colony absconding and migration}

Honeybee colonies abscond from their hives at any season of the year when the hives affected by their enemies Ayalew Kassaye (2006). According to this study about $84 \%$ of the respondent reported absconding of their honeybee colonies with the absconding incidence occurred $43.1 \%, 21.8 \%, 19.3 \%$ and $15.8 \%$ from December to February, March to May, November to September and June to August respectively (Table 8). The reason of high absconding in the months from December to February could be associated with the scarcity of bee forages and water in the area. The reported reasons for absconding of bee colonies as indicated by respondents were pests and predators $(21 \%)$, shortage of honeybee forages and water $(20.6 \%)$, poor hive manipulation $(18.3 \%)$, indiscriminate application of agrochemicals $(13.9 \%)$, bad weather condition $(8.1 \%)$, in appropriate honey harvesting techniques $(3.97 \%)$ and unknown reason $(2.2 \%)$ are the reasons for absconding. The present study is in agreement with Chala et al. (2012) who reported similar reasons for absconding in Goma district. Similarly, Kidane (2014) indicated that about $50 \%$ of the beekeepers reported having lost colonies as a result of absconding and migration in Gondere district. Shortage of bee forage causes the honeybee colony to migrate to areas where resources are available for their survival. Shortage of bee forage directly associated with off flowering period of major honeybee plants. The respondents explained that this problem often made the bees to travel several kilometers in search for available nectars which could led to the bees migrating to a closer environment to their source of food. The existence of honeybee pests and predators and off-flowering of honeybee plants ultimately resulted in frequent absconding of colonies and high migratory tendencies. During honey harvesting from traditional hives the beekeepers dismantle the hive, damage the brood, and abandon the colony results in the eventual absconding of colony. The respondents also indicated that honeybee colonies could abscond and migrate as a result of incessant disturbance or poor apiary maintenance. Since, honeybees lived a well-organized and sophisticated life; it is therefore evident that any activity that tends to affect such organized life usually led to their migration to another peaceful area where they could continue their original or planned life. 
Table 8: Causes and seasons for honeybee absconding in the study area

\begin{tabular}{|c|c|c|c|c|c|}
\hline Variable & $\begin{array}{l}\text { Adami } \\
(\mathrm{N}=40 \%)\end{array}$ & Tulu & $\begin{array}{l}\text { Arsi Negele } \\
(\mathrm{N}=40 \%)\end{array}$ & $\begin{array}{l}\text { Kofale } \\
(\mathrm{N}=40 \%)\end{array}$ & $\begin{array}{l}\text { Total } \\
(\mathrm{N}=120 \%)\end{array}$ \\
\hline \multicolumn{6}{|l|}{ Occurrence of absconding } \\
\hline Yes & 88 & & 85.7 & 79 & 84 \\
\hline No & 12 & & 14.3 & 21 & 16 \\
\hline \multicolumn{6}{|l|}{ Reasons for absconding of bee colonies } \\
\hline Incidence of pests and predators & 24.6 & & 16.5 & 22.4 & 21 \\
\hline Shortage of honeybee forages & 15.2 & & 22.2 & 24.5 & 20.6 \\
\hline Poor hive manipulation & 15.1 & & 17.3 & 22.4 & 18.3 \\
\hline Unwise application of agrochemicals & 13.6 & & 15.5 & 12.5 & 13.9 \\
\hline Shortage of water & 18.5 & & 11.5 & 5.6 & 11.9 \\
\hline Bad weather condition & 7.6 & & 9.4 & 7.2 & 8.1 \\
\hline Improper harvesting method & 4.2 & & 5.4 & 2.3 & 3.97 \\
\hline Unknown reasons & 1.2 & & 2.2 & 3.1 & 2.2 \\
\hline \multicolumn{6}{|l|}{ Seasons of absconding } \\
\hline December to February & 46.5 & & 42.4 & 40.5 & 43.1 \\
\hline March to May & 18.6 & & 23.6 & 23.1 & 21.8 \\
\hline September to November & 21.7 & & 17.5 & 18.8 & 19.3 \\
\hline June to August & 13.2 & & 16.5 & 17.6 & 15.8 \\
\hline
\end{tabular}

Control mechanism of absconding of honeybee colony in the study area

To reduce and control absconding, respondent beekeepers have different experiences like avoided the use of chemicals such as insecticides, pesticides and herbicides (16.5\%), not removing all combs during harvesting $(15.2 \%)$, provision of supplementary feeds and water during dearth period $(15 \%)$, planting of flowering plants that could supply pollen and nectar to the bees near apiary site (12\%), colony inspection regularly $(7.4 \%)$ and putting excluder at hive entrance $(11.4 \%)$.

Table 9: Control methods of absconding of honeybee colony in the study area

\begin{tabular}{|c|c|c|c|c|}
\hline Variable & $\begin{array}{l}\text { Adami Tulu } \\
(\mathrm{N}=40 \%)\end{array}$ & $\begin{array}{l}\text { Arsi Negele } \\
(\mathrm{N}=40 \%)\end{array}$ & $\begin{array}{l}\text { Kofale } \\
(\mathrm{N}=40 \%)\end{array}$ & $\begin{array}{l}\text { Total } \\
(\mathrm{N}=120 \%)\end{array}$ \\
\hline Avoid the use of chemicals near apiary site & 11.5 & 18.2 & 19.7 & 16.5 \\
\hline Close supervision of colonies & 17 & 23.5 & 8.2 & 16.2 \\
\hline $\begin{array}{l}\text { Provision of supplementary feed and water during } \\
\text { dearth period }\end{array}$ & 16.4 & 12.6 & 18.2 & 15.7 \\
\hline $\begin{array}{l}\text { Avoid total removal of honeycombs during honey } \\
\text { harvesting }\end{array}$ & 12.5 & 17.8 & 15.4 & 15.2 \\
\hline Planting of flowering plants near apiary site & 17.4 & 9.6 & 9.1 & 12 \\
\hline Putting queen excluder at hive entrance & 12.2 & 8.6 & 13.5 & 11.4 \\
\hline Colony inspection regularly & 8.5 & 5.2 & 8.4 & 7.4 \\
\hline Cleaning apiary site & 4.5 & 5.5 & 7.5 & 5.8 \\
\hline
\end{tabular}

Estimated of financial loss due to absconding of honeybees in the study area

There was financial loss due to absconding of honeybees from traditional, transitional and improved hives. A total of 758 traditional, 112 transitional and 78 modern beehives were without honeybee colonies due to absconding (Table 10). The mean honey yield of traditional hive per year is $5 \mathrm{~kg}$ multiplied by 758 give $3790 \mathrm{~kg}$. The mean honey yield of transitional hive per year is $15 \mathrm{~kg}$ multiplied by 112 give $1680 \mathrm{~kg}$. The mean honey yield of modern hive per year is $25 \mathrm{~kg}$ multiplied by 78 give $1950 \mathrm{~kg}$. Mean price of one $\mathrm{kg}$ honey during the study year, 2018/9 is 200 birr. Considering annual loss in the area, beekeeping sub sector was not exploited to its maximum.

Table 10: Financial loss due to absconding of honeybees in the study area

\begin{tabular}{llll}
\hline Hive type & Number of colony absconded & Total honey loss in $(\mathrm{Kg})$ & $\begin{array}{l}\text { Amount of money loss } \\
\text { in (ETB) }\end{array}$ \\
\hline Traditional & 758 & 4320.6 & 864,120 \\
Transitional & 112 & 1680 & 336,000 \\
Modern & 78 & 1950 & 390,000 \\
\hline
\end{tabular}

Source: Survey result, 2018 


\section{Honeybee colony swarming and means of control}

Swarming is a form of colony reproduction where by the parental colony splits into one or more subunits each containing at least one sexual female (queen) and a fraction of the colony's workers. From the total 120 respondents, about $62 \%$ replied occurrences of reproductive swarming in their apiary with the remaining about $38 \%$ had no knowhow about swarming. According to the present result the frequency of swarming of honeybee colonies in the study area were every season $(65.3 \%)$, every year $(22.8 \%)$ and once in two years $(12 \%)$. Further, most of the beekeepers reported to use many ways of controlling reproductive swarming among which use large volume of hive $(33 \%)$, suppering of hive $(26 \%)$, removal of queen cells $(19.7 \%)$, killing new emerged queen $(11.7 \%)$ and swarming return back to the colony (10\%). A result reported by Tessega (2009) indicated that the most widely used method of controlling reproductive swarming by beekeepers of Bure district of Amhara region were removal of queen cell, killing queen of the swarm and reuniting of honeybee colony to its mother, supporting and use large volume of hive as colony increase.

Table 11: Occurrence, frequency and control methods of reproductive swarming by respondents

\begin{tabular}{|c|c|c|c|c|c|c|}
\hline Parameter & $\begin{array}{l}\text { Adami } \\
(\mathrm{N}=40 \%)\end{array}$ & Tulu & $\begin{array}{l}\text { Arsi } \\
(\mathrm{N}=40 \%)\end{array}$ & Negele & $\begin{array}{l}\text { Kofale } \\
(\mathrm{N}=40 \%)\end{array}$ & $\begin{array}{l}\text { Total } \\
(\mathrm{N}=120 \%)\end{array}$ \\
\hline \multicolumn{7}{|l|}{ Occurrence of swarming } \\
\hline Yes & 47.6 & & 64.8 & & 72.5 & 62 \\
\hline No & 52.4 & & 35.2 & & 27.5 & 38 \\
\hline \multicolumn{7}{|l|}{ Frequency of swarming } \\
\hline Every season & 56.7 & & 64.5 & & 74.6 & 65.3 \\
\hline Every year & 24.5 & & 22.4 & & 21.4 & 22.8 \\
\hline Once in two years & 18.8 & & 13.1 & & 4 & 12 \\
\hline \multicolumn{7}{|l|}{ Seasons of swarming } \\
\hline September to November & 70 & & 10 & & 65 & 48.3 \\
\hline December to February & 0 & & 60 & & 20 & 26.7 \\
\hline June to August & 25 & & 20 & & 5 & 16.7 \\
\hline March to May & 5 & & 10 & & 10 & 8.3 \\
\hline \multicolumn{7}{|c|}{ Control methods of swarming } \\
\hline Use large volume of hive & 36 & & 29 & & 33 & 33 \\
\hline Suppering of hive & 25 & & 27 & & 26 & 26 \\
\hline Removal of queen cells & 16 & & 25 & & 18 & 19.7 \\
\hline Kill new emerged queen & 7 & & 11 & & 8 & 11.7 \\
\hline Return back to the colony & 16 & & 6 & & 17 & 10 \\
\hline
\end{tabular}

\section{Major constraints of beekeeping in the study area}

The major constraints of beekeeping as indicated by respondents were pests, predators and Diseases (17.6\%), shortage of bee forage (15.8\%), agrochemical poisoning (15\%), absconding and migration of honeybee colony $(10 \%)$, shortage of bee colony (9.4\%), high cost of honeybee equipments and accessories $(8.1 \%)$, recurrent drought and deforestation $(6.8 \%)$, shortage of water $(4.6 \%)$, lack of knowledge $(3.8 \%)$, poor extension services $(2.7 \%)$, poor hive management $(2.5 \%)$, inadequate of business support services $(2.1 \%)$ and bee poisoning from plants (1.5\%). The current study result was in line with Beyene et al., (2014), Gebretsadik et al. (2016), Seyoum et al. (2018) who reported that lack of bee forage, honeybee pests and predators and agro-chemicals are the major constraints of beekeeping in all regions of Ethiopia while the level of rank are varied from place to place. The present study is also in line with Kerealem et al (2009) who reported shortage of bee forage, agrochemical poisoning and honeybee pest which were also reported as the major beekeeping constraints in Amhara regional. 
Table 12: Major constraints identified by respondents in the study area

\begin{tabular}{|c|c|c|c|c|c|}
\hline Constraints & $\begin{array}{l}\text { Adami Tulu } \\
(\mathrm{N}=40 \%)\end{array}$ & $\begin{array}{l}\text { Arsi Negele } \\
(\mathrm{N}=40 \%)\end{array}$ & $\begin{array}{l}\text { Kofale } \\
(\mathrm{N}=40 \%)\end{array}$ & $\begin{array}{l}\text { Total } \\
(\mathrm{N}=120 \%)\end{array}$ & Rank \\
\hline $\begin{array}{l}\text { Honeybee pests, predators and } \\
\text { Diseases }\end{array}$ & 17 & 16.7 & 19.2 & 17.6 & $1^{\mathrm{st}}$ \\
\hline Shortage of bee forage & 13.5 & 18 & 16 & 15.8 & $2^{\text {nd }}$ \\
\hline Agrochemical poisoning & 13 & 14.3 & 17.8 & 15 & $3^{\text {rd }}$ \\
\hline $\begin{array}{l}\text { Absconding and migration of bee } \\
\text { colony }\end{array}$ & 9.6 & 10.2 & 10.4 & 10 & $4^{\text {th }}$ \\
\hline Shortage of bee colony & 11.8 & 7.8 & 8.6 & 9.4 & $5^{\text {th }}$ \\
\hline $\begin{array}{l}\text { High cost of honeybee equipments } \\
\text { and accessories }\end{array}$ & 9.4 & 8.2 & 6.6 & 8.1 & $6^{\text {th }}$ \\
\hline Recurrent drought and deforestation & 5.8 & 6.4 & 8.1 & 6.8 & $7^{\text {th }}$ \\
\hline Shortage of water & 5.2 & 4.5 & 4 & 4.6 & $8^{\text {th }}$ \\
\hline Lack of knowledge & 4.1 & 3.8 & 3 & 3.8 & $9^{\text {th }}$ \\
\hline Poor extension services & 3.6 & 2.5 & 2.1 & 2.7 & $10^{\text {th }}$ \\
\hline Poor hive management & 3.1 & 2.7 & 2.2 & 2.5 & $11^{\text {th }}$ \\
\hline $\begin{array}{l}\text { Inadequate of business support } \\
\text { services }\end{array}$ & 2.5 & 3.1 & 0.8 & 2.1 & $12^{\text {th }}$ \\
\hline Bee poisoning from plants & 1.4 & 1.8 & 1.2 & 1.5 & $13^{\text {th }}$ \\
\hline
\end{tabular}

Sources: survey, 2018

\section{Major honeybee pests and predators in the study area}

Respondents were asked to identify major honeybee pests and predators and the result indicates, the existence of pests and predators were a major challenge with other associated problems to the honeybees and beekeepers. After having identified the major pests and predators facing the beekeeping activities, farmers were requested to prioritize the challenges mentioned were ants (19.7\%), wax moth (Galleria mellonella) (17\%), honey badger (Mellivora capensis) (14.3\%), small hive beetles (Aethina tumida) (12.7\%), bee-eater birds (9.2\%), spiders (7.5\%), lizards $(6.9 \%)$, snake $(4.9 \%)$, monkey/apes $(3.2 \%)$, bee lice (Braula coecal) $(2.7 \%)$ and termite $(2 \%)$ were the most harmful pests in order of decreasing importance (Table 13). Likewise, Chala (2010) ranked ants, wax moth, honey badgers are 1st, 2nd and 3rd bee pests and enemies respectively those affect bees and beekeeping in Ethiopia. Similarly, Shenkute et al. (2012) also reported that the major honeybee enemies found in Keffa, Sheka and Bench-Maji zone are ants, honey badgers, birds and small hive beetles. Similar findings were reported by Brad (2002) revealed ants, honey badgers, bee-eater birds and wax moth devastate honeybee colonies and products especially during periods of dearth in Gondere province in Ethiopia.

Table 13: Proportion and ranks of major honeybee pests and predators in the study area

\begin{tabular}{|c|c|c|c|c|c|c|}
\hline Pests and predators & $\begin{array}{l}\text { Adami } \\
(\mathrm{N}=40 \%)\end{array}$ & Tulu & $\begin{array}{l}\text { Arsi Negele } \\
(\mathrm{N}=40 \%)\end{array}$ & $\begin{array}{l}\text { Kofale } \\
(\mathrm{N}=40 \%)\end{array}$ & $\begin{array}{l}\text { Total } \\
(\mathrm{N}=120 \%)\end{array}$ & Rank \\
\hline Ants & 20.4 & & 22 & 16.6 & 19.7 & $1^{\text {st }}$ \\
\hline Wax moth & 17.2 & & 18.7 & 15.2 & 17 & $2^{\text {nd }}$ \\
\hline Honey badgers & 16.5 & & 14.4 & 12 & 14.3 & $3^{\text {rd }}$ \\
\hline Small hive beetles & 13.3 & & 10 & 14.7 & 12.7 & $4^{\text {th }}$ \\
\hline Bee-eater birds & 8.6 & & 7.4 & 11.5 & 9.2 & $5^{\text {th }}$ \\
\hline Spiders & 7.5 & & 8.6 & 6.4 & 7.5 & $6^{\text {th }}$ \\
\hline Lizard & 5.4 & & 7.5 & 7.7 & 6.9 & $7^{\text {th }}$ \\
\hline Snake & 3.8 & & 5.3 & 5.6 & 4.9 & $8^{\text {th }}$ \\
\hline Monkey/apes & 2.7 & & 2.4 & 4.5 & 3.2 & $9^{\text {th }}$ \\
\hline Bee lice & 3 & & 2.2 & 2.9 & 2.7 & $10^{\text {th }}$ \\
\hline Termite & 1.6 & & 1.5 & 2.9 & 2 & $11^{\text {th }}$ \\
\hline
\end{tabular}

Traditional control methods of major honeybee pests and predators

Beekeepers practice different control methods to overcome problems of pests and predators of honeybee. They use numbers of traditional control methods base up on the type target enemies either individually or in combination with modern control methods (Table 14). 
Table 14: Traditional methods used by beekeepers for control and management honeybee pests and predators in the study area

\begin{tabular}{|l|l|l|}
\hline $\begin{array}{l}\text { Pests and } \\
\text { predators }\end{array}$ & $\begin{array}{l}\text { Season of } \\
\text { occurrence }\end{array}$ & Control methods \\
\hline Ants & Year-round & $\begin{array}{l}\text { Frequent smoking, plastering hive stand with plastic, using local olum } \\
\text { Africana/eucalyptus leaf for fumigation, daily follow up and using hot } \\
\text { water, using ash, destroying ants nests, killing the queen of ant and smooth } \\
\text { iron sheets }\end{array}$ \\
\hline Wax moth & Winter & $\begin{array}{l}\text { Cleaning the apiary site, remove old comb, strengthen the colon, seasonal } \\
\text { management and daily supervision }\end{array}$ \\
\hline Bee lice & Year-round & Cleaning the apiary and make the colony strong \\
\hline Hive beetles & Winter and & $\begin{array}{l}\text { Cleaning the apiary, narrowing the hive entrance, hand picking and kill and } \\
\text { seasonal management }\end{array}$ \\
\hline Spiders & Year-round & $\begin{array}{l}\text { Make narrow hive entrance, cleaning the apiary, removing of spider's web, } \\
\text { killing and follow up }\end{array}$ \\
\hline Lizard & Year-round & Removing their nesting site and killing \\
\hline Snake & Year-round & Clean apiary and killing \\
\hline Monkey/apes & Year-round & No measures taken \\
\hline Birds & Year-round & $\begin{array}{l}\text { Placing the seeming image of human near the hives using cloth, plastics, } \\
\text { using stone }\end{array}$ \\
\hline Honey badger & Year- round & $\begin{array}{l}\text { Use of smooth iron sheet on hive stand, putting barriers, fencing with } \\
\text { thorny plants, hanging hives by rope on long trees and chasing with dogs }\end{array}$ \\
\hline Termite & Summer & Burning, killing and destroying termite nests \\
\hline
\end{tabular}

\section{Conclusion and recommendations}

The study demonstrated that honey productions in the study area is dominated by traditional practices and constrained by pests, predators and Diseases, shortage of bee forage, agrochemical poisoning, absconding and migration of honeybee colony, shortage of bee colony, high cost of honeybee equipments and accessories, recurrent drought and deforestation, shortage of water, lack of knowledge, poor extension services, poor hive management, inadequate of business support services and bee poisoning from plants. Furthermore, ants, wax moth (Galleria mellonella), honey badger (Mellivora capensis), small hive beetles (Aethina tumida), bee-eater birds, spiders, lizards, snake, monkey/apes, bee lice (Braula coecal) and termite were found harmful pests and predators of honeybee in the study area. From the study it was understood that the honey yield is decreasing from time to time due to climate change. Colony absconding and swarming had been the major problems confronting beekeepers which had led to total loss or reduction in production of honey and other honeybee products. It could be concluded from the results of this study that pests and predators' invasion, shortage of bee forages, poor hive management, indiscriminate application of agrochemicals, bad weather condition, shortage of water and improper harvesting methods were the most prominent and significant causes of honeybees colony absconding in the area.

Based on the above conclusive remarks the following recommends are forwarded:

- Efforts should be geared to alleviate the main constraints that hindered beekeeping development in the study area

- Strengthening the extension services and technical intervention in the area to enhance the development of improved beekeeping that can significantly increase the quantity and quality of honey yield

- Beekeepers are also advised to avoid total removal of honeycombs from the hives during honey harvesting which avoid destruction of the colony and absconding

- Regularly inspection/maintenance of the apiary, avoiding the use of chemicals near apiary site and planting of flowering plants to supply nectars and pollen in the apiary should be ensured by the beekeepers in the area.

- Every beekeeper should get basic training on colony management practices reduce absconding and migration rate

- Indigenous knowledge of farmers in beekeeping should be scientifically examined

\section{Acknowledgement}

The authors would like to acknowledge Adami Tulu Agricultural Research Center for the materials, logistics and financial supports. We also thankful to the development agents and beekeepers working in the study area for their willingness to be interviewed and for giving us all necessary information. 


\section{Disclosure Statement}

The authors declare that they have no conflict of interests

\section{References}

Adeday Gidey, Shiferaw Mulugeta and Abebe Fromsa (2012): Prevalence of Bee Lice Braula Coeca (Diptera: Braulidae) and Other Perceived Constraints to Honey Bee Production in Wukro Woreda, Tigray Region, Ethiopia. Global Veterinaria v. 8 (6): 631-635.

Adgaba, A. Al, Ghamdi, A.G. Shenkute, S. Ismaiel S. Al, Y. Kahtani, M.J. Tadess, W. Ansari, M.Q Abebe, and A. Abdulaziz, 2014. Socio economic analysis of beekeeping and determinants of box hive technology adoption in the kingdom of Saudi Arabia. The Journal of Animal \& Plant Sciences, 24(6):1876-1884.

Ayalew Kassaye (2006) The loss of some natural plant species in Tigray and the concern to the living conditions of honeybees. Proceedings of the 5th Annual National Conference of Ethiopian Beekeepers Association 815

Ayalew Kassaye, 2001. Promotion of Beekeeping in the Rural Sector of Ethiopia. In proceedings of the $3^{\text {rd }}$ Ethiopian beekeeper's association (EBA).

Beyene T and David P. 2007. Ensuring Small Scale Producers in Ethiopia to Achieve Sustainable and Fair Access to Honey Markets. Paper prepared for international development enterprises (IDE) and Ethiopian society for appropriate technology (ESAT), Addis Ababa, Ethiopia.

Beyene Taye and Verschuur Marco. 2014. Assessment of constraints and opportunities of honey production in Wonchi District South West Shewa Zone of Oromia, Ethiopia. American Journal of Research Communication, 2(10):342-353.

Brad, B. 2002. Taking the sting out of Beekeeping rid lands of information network East Africa (CD-Rom), pp: 1 -

CSA. (2009), Statistical Abstracts. Addis Ababa, Ethiopia: Central Statistical Agency.

CSA. 1995. (Central Statistical Authority). Agricultural Sample Survey: Report on Livestock, Poultry and Beehives Population, Vol. II, No 132, CSA, Addis Ababa, Ethiopia. p.28.

Chala K, Taye T, Kebede D, Tadele T, (2012) Opportunities and challenges of honey production in Gomma District of Jimma Zone, south-west Ethiopia. Journal.

Edessa N. (2002). Survey on honey production system in West Shoa Zone. Holeta Bee Research Center (HBRC), Ethiopia

EAR (Ethiopian Agricultural Research Organization) (2000). Apiculture research strategy, Ethiopian Agricultural Research Organization, Animal Science Research Directorate, 45p

Fikru S, Gebresilassie G, Kassa A. 2015. Assessment of Beekeeping Practices (Absconding, Bee Forage and Bee Diseases and Pests) in Jigjiga Zone, Somali Regional State of Ethiopia. Poultry, Fisheries and Wildlife Sciences, 3:135

Gebretsadik Teklu, and Negas Dinku. 2016. "Honeybee production system, challenges and opportunities in selected districts of Gedeo Zone, Southern Nation, Nationalities and Peoples Regional State, Ethiopia international journal of research, 4:49-63.

Gebretsadik Teklu. 2016. Survey on honeybee pests and predators in Sidama and Gedeo zones of Southern Ethiopia with emphasis on control practices. Agriculture and Biology, Journal of North America.

Getachew Abrham. 2018. Assessment on the Constraints and Practices of Beekeeping, and Post Harvest Honey Handling in Gesha District, Keffa Zone, South-West Ethiopia. Agricultural Research and Technology: Open Access Journal, 16(1): 555974.

Gezahegne Tadesse. 2001b. Marketing of honey and beeswax in Ethiopia: past, present and perspective features: Proceedings of the third National Annual Conference of the Ethiopian Beekeepers Association (EBA), September 3-4, 2001, Addis Ababa, Ethiopia, pp. 78-88.

Guesh Godifey. 2015. Epidemiology of Honey Bee Disease and Pests in Selected Zones of Tigray Region, Northern Ethiopia. MSc Thesis. Bahir Dar University. Bahir Dar, Ethiopia, 124.

Haftu Kebede and Gezu Tadesse. 2014. Survey on honeybee production system, challenges and opportunities in selected areas of Hadiya Zone, Ethiopia. Journal of Agricultural Biotechnology and Sustainable Development, 6(6):60-66.

Kalayu A, Wondifraw Z and Tiruneh W. 2017. Beekeeping Practice and Honey Production in North-East Dry Land Areas of Amhara National Regional State, Ethiopia. Poultry, Fisheries and Wildlife Sciences, 5: 187.

Kerealem Ejigu, Tilahun Gebey and Preston T R 2009 Constraints and prospects for Apiculture Research and Development in Amhara region, Ethiopia.

Martey, E., Wiredu, A.N., Asante, B.O., Annin, K., Dogbe W., Attoh, C. and Al-Hassan, R.M. 2013. Factors influencing participation in rice development projects: The case of smallholder rice farmers in Northern Ghana. International Journal of Development and Economic Sustainability, 1(2):13-27.

MOA (Ministry of Agriculture) (2003. Comprehensive bees and beeswax marketing, 2nd draft. MOA, Addis 
Ababa, Ethiopia

Nuru Adgaba. 2007. Atlas of pollen grains of major honeybee flora of Ethiopia. Holeta Bee Research center. Council Directive 2001/110/EC of 20 December 2001 relating to honey. Official Journal of the European Communities, 10: 47-52.

Nuru Adgaba. 2002. "Geographical races of the Honeybees (Apis mellifera L.) of the Northern Regions of Ethiopia. PhD dissertation. Rhodes University, South Africa. Paterson PD, 265.

Oromia Regional State Finance and Economic Development Office (OFEDO) (2009). West Arsi zonal Map4

Qaiser, T., Ali, M., Taj, S., Akmal, N. (2013), Impact assessment of beekeeping in sustainable rural livelihood. Journal of Social Sciences 2, 82-90.

Mites (G. R. Needham, R. E. Page, Jr., M. Delfinado-Baker and C. Bowman, Eds.) West view Press, Boulder, Colorado, pp. 13-28.

Seyoum Elifyos and Anja Abera. 2018. Assessment of beekeeping production system and constraints in basketo special woreda, Southern Ethiopia. Horticulture International Journal, 2(3):124-127.

Shenkute AG, Getachew Y, Assefa D, Adgaba N, Gebeyehu G, Abebe W (2012).Honey production system(Appis mellifera) in Kafa ,Sheka and Benchi-Maji zones of Ethiopia. JAgric Ext Rural Deve 4 (19):528-541

Tessega Belie. 2009. Honeybee production and marketing systems, constraints and opportunities in Burie District of Amhara Region, Ethiopia. MSc thesis (Animal Production). Bahir Dar University, Bahir Dar, Ethiopia.

Tezera Awoke. 2013. Honey Market Constraints and Opportunities in the Case of Lasta Woreda North Wollo Zone, Amhara Regional State, Ethiopia. MA Thesis. Mekelle University, College of Business and Economics, Department of Management. Mekelle, Ethiopia. 115.

Thrusfield, M. (2005): Veterinary epidemiology. (3rd edn), Blackwell publishers, London

Workneh Abebe. 2007. Determinants of Adoption of Improved Box Hive in AtsbiWemberta District of Eastern Zone, Tigray Region. MSc. Thesis. Haramaya University, Ethiopia, 131. Winston, M.L., 1987. The Biology of the Honey Bee. Harvard University Press, Cambridge, Massachusetts, USA.

Yirga, G., Teferi, M. (2010), Participatory technology and constraints assessment to improve the livelihood of beekeepers in Tigray Region, northern Ethiopia. Momona Ethiopian Journal of Science 2, 76-92 